\title{
New records of the rare shrimp parasite Zonophryxus quinquedens Barnard, 1913 (Crustacea, Isopoda, Dajidae): ecological and phylogenetic implications
}

Received: 25 April 2005/ Accepted: 22 August 2005/Published online: 19 October 2005

(C) Springer-Verlag 2005

\begin{abstract}
The rare dajid, Zonophryxus quinquedens represents the only known isopod parasiting on shrimps in Antarctic waters. In contrast to the Bopyridae, which typically live in the gill cavity of their crab host, dajid isopods are normally attached to the carapace of the parasited shrimp. Four specimens of $Z$. quinquedens Barnard, 1913 were collected in the eastern and western Weddell Sea, Antarctica, during the expeditions ANT XXI/2 in 2003/2004 and ANT XXII/3 in 2005. Molecular phylogenetic analyses, based on small subunit rRNA gene sequences, indicate a close relationship of $Z$. quinquedens to the Bopyridae. Possible ecological and physiological aspects of the parasite-host interaction are discussed.
\end{abstract}

\section{Introduction}

The scarcity of decapod crustaceans is one of the most striking biodiversity characteristics of Antarctic waters when compared to other seas (Thatje and Arntz 2004), caused by physiological as well as ecological factors (e.g., Clarke 1983; Thatje et al. 2003). On the high Antarctic continental shelf only five benthic shrimp species are known (Gorny 1999). In contrast to the decapod crustaceans, the peracarid crustaceans, especially the Amphipoda and Isopoda, have flourished in terms of diversity in Antarctic waters (e.g., Brandt 1991, 2000). Among these, parasitic forms have received little attention in the past. Parasitic isopods with a highly modified morphology, strong sexual dimorphism, and

M. J. Raupach ( $\varangle)$

Lehrstuhl für Spezielle Zoologie, Fakultät für Biologie,

Ruhr-Universität Bochum, Universitätsstraße 150,

Bochum 44780, Germany

E-mail: michael.raupach@rub.de

\section{S. Thatje}

National Oceanography Centre, University of Southampton, European Way, Southampton SO14 3ZH, UK strange life cycles, occur in the taxon Cymothoida Wägele, 1989 (e.g., the Gnathiidae Leach, 1814). In particular the Bopyridae are important isopod parasites of decapods. Although our knowledge of their life history and physiology is extremely limited, they are known to frequently infest lithodid crabs (Roccatagliata and Lovrich 1999, and references therein). Host-parasite interactions in the Lithodidae are known from subantarctic waters, albeit records of bopyrids are still lacking from high Antarctic lithodids.

As for the Antarctic shrimp only the host-parasite interaction between the enigmatic isopod $Z$. quinquedens (Isopoda, Cymothoida, Dajidae) (Fig. 1a) and Nematocarcinus lanceopes has been described so far (Brandt and Janssen 1994). Shrimps of the genus Nematocarcinus (see Fig. 1b) are common in Antarctic deep waters (Wägele and Sieg 1990), but specimens were found even in the Cape basin (see also Thatje et al. 2005a; Linse et al. 2005). Morphological studies indicate a close relationship of the Dajidae and Bopyridae (Wägele 1989), but the classification is still in discussion (Martin and Davis 2001; Brandt and Poore 2003). In contrast to the Bopyridae, which are known to infest their host in the branchial chamber below the carapace, the Dajidae are parasites typically attached to the carapace of euphausiids, mysids, and shrimps (see Fig. 1c), although some may also be found on the host gills or attached to the carapace of their hosts.

Within the genus Zonophryxus, six different species have been described from polar, temperate, and tropical waters until now: Z. dodecapus Holthuis, 1949 (Canary Islands), Z. grimaldii Koehler, 1911 (Spain), Z. quinquedens Barnard, 1913 (South Africa), Z. retrodens Richardson, 1904 (Hawaii), Z. similes Richardson, 1914 (Hudson Bay), and Z. trilobus Richardson, 1910 (Philippines). Z. quinquedens is currently known only from three different locations, all located in the Southern Hemisphere: $18^{\circ} 29^{\prime} \mathrm{E} 34^{\circ} 21^{\prime} \mathrm{S}$ (Cape Point area) at 840-1,250 m (Barnard 1913), $48^{\circ} \mathrm{W} 62^{\circ} \mathrm{S}$ (Powell Basin) at unkown depth (Lopretto 1983) and $05^{\circ} 08^{\prime} \mathrm{W}$ 69 $58^{\circ} \mathrm{S}$ (eastern Weddell Sea) at $665 \mathrm{~m}$ (Brandt and Janssen 1994). 
Fig. 1 a Female and dwarf male (arrow) of $Z$. quinquedens Barnard, 1913 (Crustacea, Isopoda, Dajidae) in ventral (left) and dorsal (right) view, scale bar $=5 \mathrm{~mm}$; b $N$. lanceopes (Bates 1888), lateral view, scale bar $=1 \mathrm{~cm}$; drilling hole (arrow) of a female specimen of $Z$. quinqudens on the carapace of $N$. lanceopes
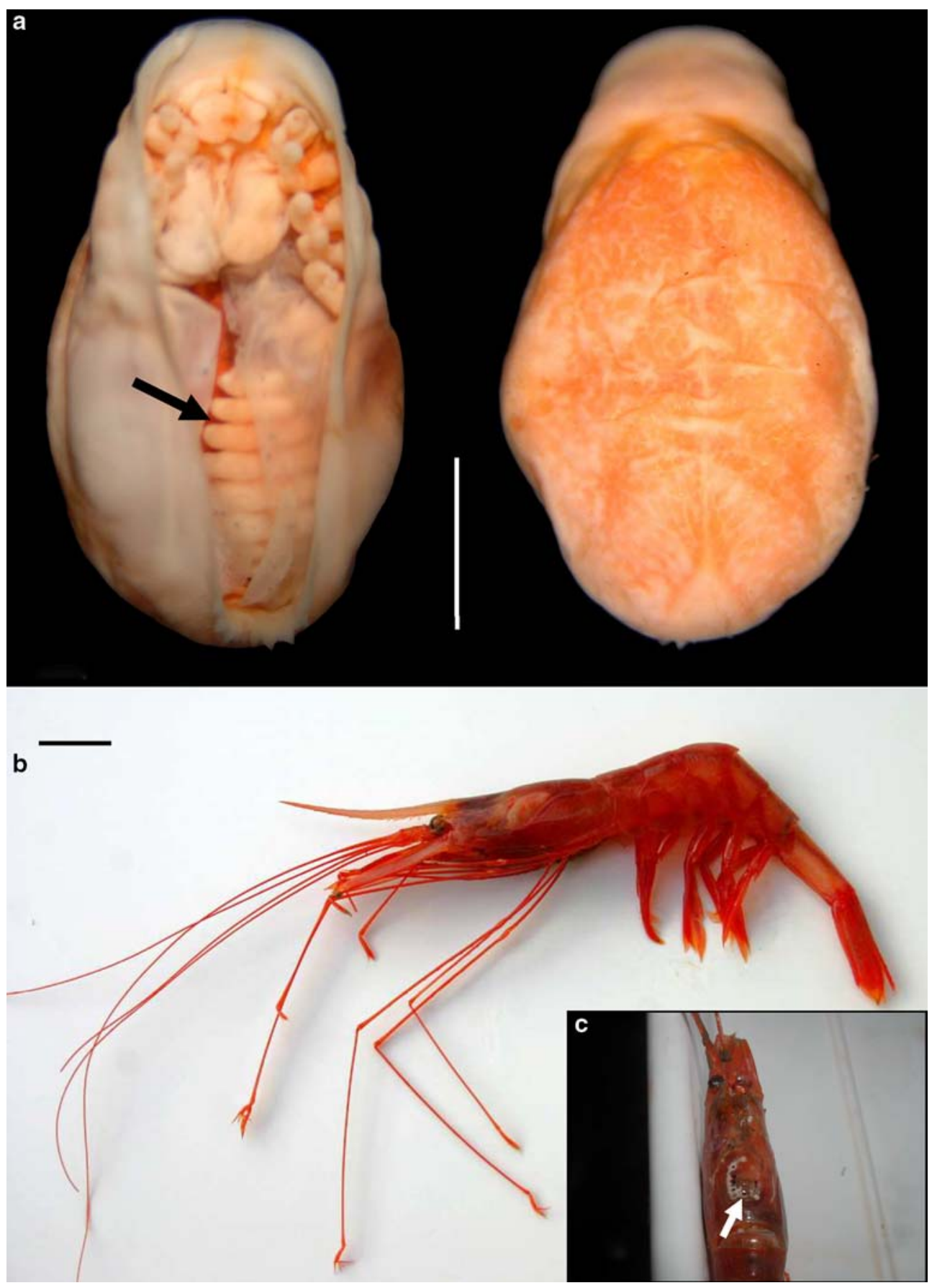

The present work gives insight into the phylogenetic position of $Z$. quinquedens within the Cymothoida using ssu rRNA gene sequences and some possible ecological and physiological aspects of the parasite-host interaction.

\section{Material and methods}

\section{Specimens}

A single female specimen of $Z$. quinquedens was separated from an epibenthic sledge sample taken in the eastern Weddell Sea (PS65/232-1: $13^{\circ} 56^{\prime} \mathrm{W} 71^{\circ} 18^{\prime} \mathrm{S}$ ) at
900-910 m water depth during the expedition ANT XXI/2 in December 2003. In addition, one female and one male were collected in the eastern Weddell Sea (PS67/074-7: $13^{\circ} 58^{\prime} \mathrm{W} 71^{\circ} 18^{\prime} \mathrm{S}, 1,030-1,040 \mathrm{~m}$ depth) and one female in the western Weddell Sea (PS67/151-1: $47^{\circ} 07^{\prime} \mathrm{W} 61^{\circ} 45^{\prime} \mathrm{S}$ during ANT XXII/3 (ANDEEP III) in February 2005 . The animals were immediately transferred into $96 \%$ ethanol for preservation. The benthos material obtained from the epibenthic sledge (ANT XXI/2) and Agassiz trawl (ANT XXII/3) contained 74, respectively, 84 specimens of the deep-sea shrimp $N$. lanceopes (Bate 1888), known as host of $Z$. quinquedens (Brandt and Janssen 1994). 
Additional sequences included in the DNA analyses were obtained from GenBank and included all available cymothoids except Paragnathia formica (AF255687), which is being known as being a long-branched taxon (see Dreyer and Wägele 2001 for details). The following sequences were used for outgroup comparison: Decapoda: Astacus astacus (AF235959), Stomatopoda: Squilla empusa (X01723), Isopoda (Anthuridea): Cyathura carinata (AF332146), and Paranthura nigropunctata (AF279598).

DNA extraction, PCR, and sequencing

Methods for DNA extraction, amplification (including primers), and sequencing are given elsewhere (Raupach et al. 2004). Total genomic DNA was extracted from one leg of one specimen (female, ANT XXI/2). The new ssu rDNA sequence can be retrieved from GenBank (DQ008451).

Alignment and phylogenetic analyses

All 14 ssu rDNA sequences used were aligned using CLUSTAL X on default parameters (Thompson et al. 1997), generating an alignment of 3,546 base pairs (bp). Variable regions within ribosomal RNAs, especially in isopods, can greatly vary in length, which makes it almost impossible to establishing the base homology between distantly related species (e.g., Choe et al. 1999; Dreyer and Wägele 2001). Highly variable and nonalignable regions within the alignment were identified using the secondary structure of the ssu rRNA in the decapod A. astacus (Wuyts et al. 2002). Therefore most parts of the expansion segments V4, V7, V9 and some other helices were excluded from further phylogenetic analyses (definitions in parentheses refer to the helix numbering of ssu rRNAs): 76-86 [E_6], 133-151/183447 [E 8-E 11], 821-1974 [E 23/1-E23/17 = V4], 2505-3011 [E 43/1-E_43/4 = V7], and 3336-3460 [E 49 $=$ V9]. The final alignment used for this study had 1,464 bp; both alignments are available from the authors.

The homogeneity of base frequency versus taxa was tested using the $\chi^{2}$-test implemented in PAUP*4.0b10 (Swofford 2002). Sequences were analysed using a Bayesian approach with the program MrBayes 3.1 (Huelsenbeck and Ronquist 2001), with clade support assessed by posterior probability, on default parameters. Trees were sampled every 100 generations, yielding 9,000 samples of the Markov chain after a "burn in" of 1,000 generations. The appropriate model of nucleotide substitution for the Bayesian analyses was determined by using the Akaike Information Criterion (Akaike 1974), implemented in MODELTEST version 3.7 (Posada and Crandall 1998), which has several important advantages over the hierachical likelihood ratio test (hLRT) (see Posada and Buckley 2004 for details).

\section{Results}

All analysed sequences deviate somewhat from the expected base frequencies (A:C:G:T = 0.26:0.23:0.27:0.24), but there are no significant differences in base composition ( $\chi^{2}$ test: $d f=39, P=0.99$ ). Plots of transitions and transversions versus evolutionary distances indicated no substitution saturation (not shown). The Akaike Information Criterion suggests the use of the general timereversible model (Tavare 1986) with gamma-distributed rates for the ssu rRNA gene dataset (alpha $=0.68$, Pinvar $=0.40, R_{(\mathrm{AC})}=1.05, R_{(\mathrm{AG})}=2.73, R_{(\mathrm{AT})}=1.46$, $\left.R_{(\mathrm{CG})}=0.72, R_{(\mathrm{CT})}=4.17, R_{(\mathrm{GT})}=1.00\right)$ as parameters for the Bayesian analyses.

The tree resulting from the Bayesian analysis is provided in Fig. 2. The stomatopod $S$. empusa and the decapod A. astacus were used to root the trees. The topology supports the monophyly of the Cymothoida (1.00). Further groups recovered with high support are the Cymothoidae (1.00) and Bopyridae (1.00). $Z$. quinquedens appears as the sister taxon of the Bopyridae (0.95). The monophyly of the Cirolanidae is not supported.

\section{Discussion}

Despite the small number of cymothoid sequences, these analyses reveal some insights into the phylogeny of this taxon. Nevertheless, additional sequences are urgently needed to reconstruct the phylogeny of the Cymothoida. The Bayesian analyses strongly support the monophyly of the Cymothoidea and Bopyridae, but the results do not support a sister-group relationship of these two taxa as suggested by other molecular studies (Dreyer and Wägele 2001, 2002). In addition, no evidence was found for the monophyly of the Cirolanidae. However, ssu rDNA data support the hypothesis that $Z$. quinquedens is closely related to the Bopyridae, as it is also suggested by some morphological evidence (Wägele 1989; Brandt and Poore 2003).

Mobility represents an important trait for the female $Z$. quinquedens because the parasitic isopod has to move from the cast exuvia to the fresh carapace of its host when it moults. Moulting in adult Antarctic shrimp has only been described in Chorismus antarcticus from the Weddell Sea shelf (Thatje et al. 2005b). The moulting in one female of $C$. antarcticus observed in the laboratory, from rupture of the carapace to leaving the exuvia, surprisingly lasted only about $3 \mathrm{~min}$ (Thatje et al. 2005b). A few abdominal flappings, as typically found in escape attempts of shrimps, were performed to leave the exuvia. If this moulting pattern is similar in $N$. lanceopes, the moult of the host should be a crucial moment in the life history of the isopod. This may be determined by changes in the host's steroid levels in the haemolymph. As an ectoparasite, $Z$. quinquedens should use its reduced but functional peraeopods to move from the 
Fig. 2 Bayesian consensus tree based on an alignment of 1,464 bp from the ssu rRNA gene. Model choice based on the Akaike Information Criterion: Six substitution types (GTR model) with gammadistributed rates (alpha $=0.68)$ and invariant positions (Pinvar $=0.40)$. Numbers at the nodes represent posterior

probabilities; values below 0.50 are not shown

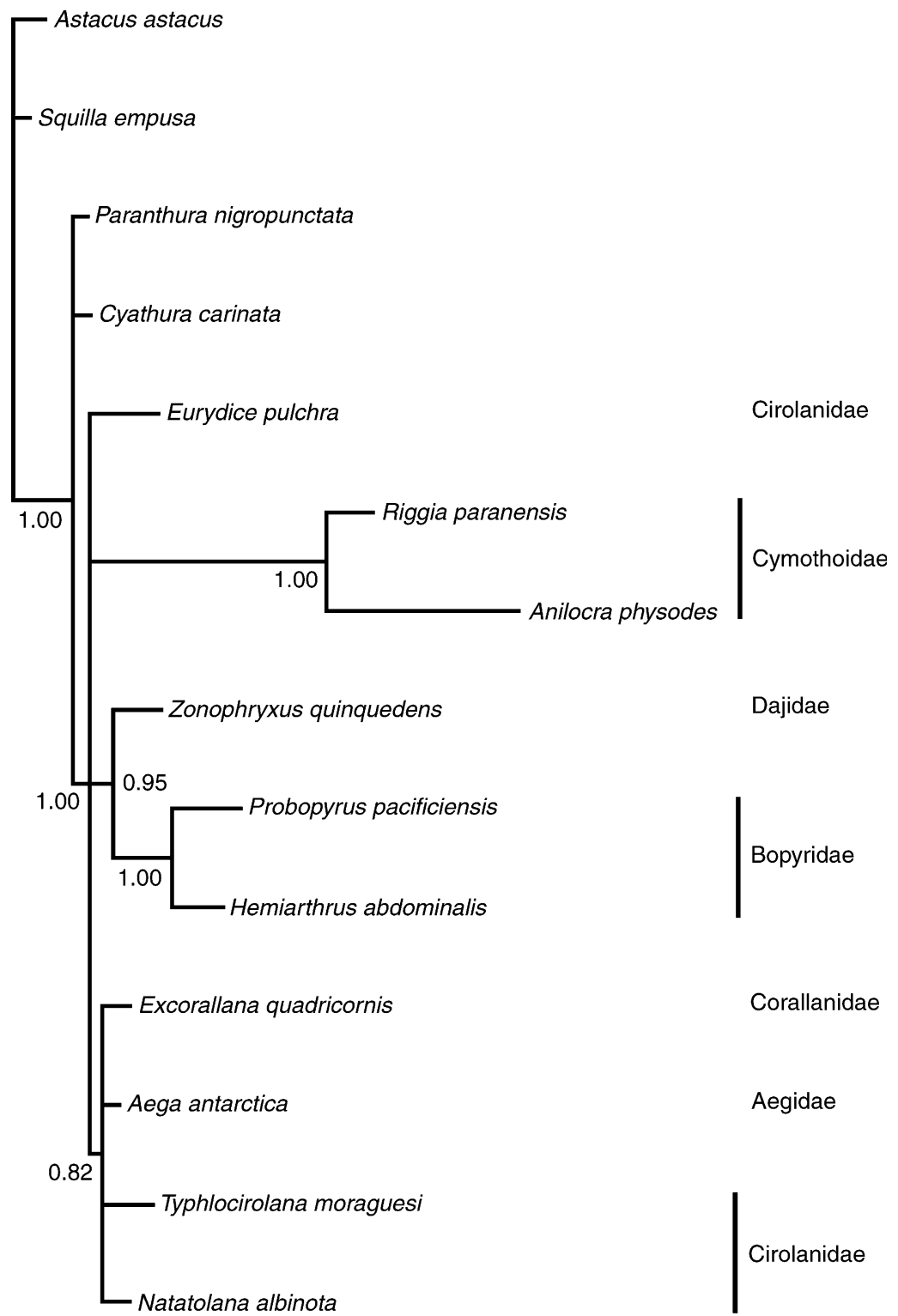

0.1 substitutions/site

cast exuvia to the fresh carapace of the host during moult; all this has to take place within a very short time period. The fresh and still soft carapace should facilitate the infestation of the host by the isopod, and it is remarkable to observe that the reduced and modified legs of Zonophryxus do indeed superficially penetrate the carapace of Nematocarcinus (Fig. 1c), which is a strong hint for a continuous infestation after moult. However, most aspects of this enigmatic isopod are still unknown and thus remain in speculation, and biochemical analyses are urgently needed to understand the physiology of this remarkable parasite.

Acknowledgements We are grateful to Angelika Brandt for organizing the expeditions ANDEEP III (ANT XXII/3), and to Wolf Arntz for managing ANT XXI/2. We would like to thank Manuel Ballesteros (Centro de Estudios Avanzados de Blanes) for provid- ing the material (ANT XXI/2) and Katrin Linse (British Antarctic Survey) for her help with digital photography of $Z$. quinquedens. Bhavani Narayanaswamy (Scottish Association for Marine Science) provided constructive comments. The first author is indebted to the German Science Foundation (DFG) for co-financing his participation on the Polarstern cruise (grant WA 530/26). We would like to thank three anonymous reviewers for comments on the manuscript.

\section{References}

Akaike H (1974) A new look at the statistical model identification. IEEE Trans Autom Contr 19:716-723

Barnard KH (1913) Contributions to the crustacean fauna of South Africa. Ann S Afr Mus 10:197-240

Bate CC (1888) Report on the Crustacea Macura collected by HMS Challenger during the years 1873-76. Part 1. Rep Voy Challenger 24:1-929 
Brandt A (1991) Zur Besiedlungsgeschichte des antarktischen Schelfes am Beispiel der Isopoda (Crustacea, Malacostraca). Berichte zur Polarforschung (Rep Polar Res) 98:1-240

Brandt A, Janssen HH (1994) Redescription of Zonophryxus quinquedens Barnard, 1913 (Crustacea, Isopoda, Dajidae) from the Weddell Sea, Antarctica, with notes on its biology and zoogeography. Polar Biol 14:343-350

Brandt A (2000) Hypotheses on Southern Ocean peracarid evolution and radiation (Crustacea, Malacostraca). Ant Sci 12(3):269-275

Brandt A, Poore GCB (2003) Higher classification of the flabelliferan and related Isopoda based on a reappraisal of relationships. Inv Syst 17:893-923

Choe CP, Hancock JM, Hwang UW, Kim W (1999) Analysis of the primary sequence and secondary structure of the unusually long ssu rRNA of the soil bug, Armadillidium vulgare. J Mol Evol 49:798-805

Clarke A (1983) Life in cold waters: the physiological ecology of polar marine ectotherms. Oceanogr Mar Biol Ann Rev 21:341453

Dreyer H, Wägele JW (2001) Parasites of crustaceans (Isopoda: Bopyridae) evolved from fish parasites: molecular and morphological evidence. Zoology 103:157-178

Dreyer H, Wägele JW (2002) The Scutocoxifera tax nov. (Crustacea, Isopoda) and the information content of nuclear ssu rDNA sequences for reconstruction of isopod phylogeny (Peracarida: Isopoda). J Crust Biol 22:217-234

Gorny M (1999) On the biogeography and ecology of the Southern Ocean decapod fauna. Scientia Marina 63 (Suppl 1):367-382

Holthuis LB (1949) Zonophryxus dodecarpus nov. spec., a remarkable species of the family Dajidae (Crustacea: Isopoda) from the Canary Islands. Koninklijke Nederlandsche Akademie van Wetenschnappen 53(3):3-8

Huelsenbeck JP, Ronquist F (2001) MrBayes: Bayesian inference of phylogenetic trees. Bioinformatics 17:754-755

Koehler R (1911) Isopodes nouveaux de la famille Dajides provenant des campagnes de la "Princesse Alice". Bull Inst Oceanogr Monaco 196:1-34

Leach WE (1814) Crustaceology. In: Brewster's Edinburgh Encyclopedia 7:383-437

Linse K, Brandt A, Bohn J, Danis B, Heterier V, Janussen D, Lopéz Gonzales PJ, Schwabe E, Thomson MR (2005) Megabenthos collected by the Agassiz trawl. In: Fahrbach E, Brandt A (eds): Die Expedition ANT XXII/3 des Forschungsschiffes Polarstern. Ber Polar Meeresforsch (Rep Polar Mar Res) (in press)

Lopretto EC (1983) Zonophryxus quinquedens Barnard (Isopoda, Epicaridea, Dajidae) in South Orkney Islands waters. In: ElSayed SZ, Tomo AP (eds) Biological investigations of Marine Antarctic Systems and Stocks (Biomass) vol. 7: Ant Aquat Biol:87-97

Martin JW, Davis GE (2001) An updated classification of the recent Crustacea. Sci Ser 39:1-124
Posada D, Crandall KA (1998) MODELTEST: testing the model of DNA substitution. Bioinformatics 14:817-818

Posada D, Buckley TR (2004) Model selection and model averaging in phylogenetics: advantages of akaike information criterion and Bayesian approaches over likelihood ratio tests. Syst Biol 53:793-808

Raupach MJ, Held C, Wägele JW (2004) Multiple colonization of the deep sea by the Asellota (Crustacea: Peracarida: Isopoda). Deep-Sea Res II 51:1787-1795

Richardson H (1904) Contributions to the natural history of the Isopoda. Proc US Nat Mus 27:657-681

Richardson H (1910) Marine isopods collected in the Phillippines by the US Fisheries Commission Streamer "Albatross" in 19071908. Doc US Bur Fish 736:1-44

Richardson H (1914) Reports on the scientific results of the expedition to the tropical Pacific in charge of Alexander Agassiz, on the U.S. Fish Commission Streamer "Albatross". Bull Mus Comp Zool Harvard 58:361-372

Roccatagliata D, Lovrich GA (1999) Infestation of the False King Crab Paralomis granulosa (Decapoda: Lithodidae) by Pseudione tuberculata (Isopoda: Bopyridae) in the Beagle Channel, Argentina. J Crust Biol 19(4):720-729

Swofford DL (2002) PAUP*: phylogenetic analysis using parsimony (* and other methods) Version 4.0b10. Sinauer Associates, Sunderland, Massachusetts

Tavare S (1986) Some probabilistic and statistical problems in the analysis of DNA sequences. In: Miura RM (ed) Some mathematical questions in biology-DNA sequence analysis. pp 5786

Thatje S, Schnack-Schiel S, Arntz WE (2003) Developmental tradeoffs in Subantarctic meroplankton communities and the enigma of low decapod diversity in high southern latitudes. Mar Ecol Prog Ser 260:195-207

Thatje S, Arntz WE (2004) Antarctic reptant decapods: more than a myth? Polar Biol 27:195-201

Thatje S, Bacardit R, Arntz WE (2005a) Larvae of the deep-sea Nematocarcinidae (Crustacea: Decapoda: Cardidea) from the Southern Ocean. Polar Biol 28:290-302

Thatje S, Lavaleye M, Arntz WE (2005b) Reproductive strategies of Antarctic decapod crustaceans. Ber Polar Meeresforsch (Rep Polar Mar Res) 503:28-30

Thompson JD, Gibson TJ, Plewniak F, Jeanmougin F, Higgins DG (1997) The Clustal X windows interface: flexible strategies for multiple sequence alignment aided by quality analysis tools. Nucl Acids Res 24:4876-4882

Wägele JW (1989) Evolution und phylogenetisches System der Isopoda: Stand der Forschung und neue Erkenntnisse. Zoologica 140:1-262

Wägele JW, Sieg J (eds) (1990) Fauna der Antarktis. Verlag Paul Parey, $197 \mathrm{pp}$

Wuyts J, Van de Peer Y, Winkelmans T, De Wachter R (2002) The European database on small subunit ribosomal RNA. Nucl Acids Res 30:183-185 